\title{
Understanding the Social Studies Curricula in Turkey as a Political Text Within the Context of Citizenship Education: Views of Academics and Teachers
}

\author{
Fadıl Şiraz ${ }^{1} \&$ Erdal Bay ${ }^{2}$ \\ ${ }^{1}$ Uluonder Special Education and Application Center, Directorate of National Education, Eskişehir, Turkey \\ ${ }^{2}$ Faculty of Economics, Administrative and Social Sciences, Gaziantep Islam Science and Technology University, \\ Gaziantep, Turkey \\ Correspondence: Erdal Bay, Faculty of Economics, Administrative and Social Sciences, Gaziantep Islam Science \\ and Technology University, Beştepe Dis. 192180 St. 27010 Şahinbey/Gaziantep, Turkey. E-mail: \\ fadilsiraz@yahoo.com
}

Received: January 8, 2021

Accepted: March 24, 2021

Online Published: May 14, 2021

doi:10.5539/ies.v14n6p34

URL: https://doi.org/10.5539/ies.v14n6p34

\begin{abstract}
This study attempted to understand the curricula in conveying the state's own understanding to individuals, according to the reconceptualization approach. As content, the social studies curricula (SSC), with the assumption that political influence would be seen most in these curricula, were examined. This study aims understanding the social studies curricula as a political text within the context of citizenship education in order to see how politics affect these curricula. To determine what political factors affected SSCs in which way, the opinions of academics and teachers were examined regarding curricula from 1998, 2005 and 2018, prepared during different government periods in Turkey. It was tried to determine how the changes in SSCs were defined in political/non-political dimensions, explanation and definition, the criticism, reasons and recommendation regarding these changes. This study was designed as a case study, one of the qualitative methods. Data analysis was done by content analysis method. It was determined that the changes in social studies curricula in 1998, 2005 and 2018 were affected by different political reasons and that there were some prominent ideological elements in all 3 curricula. As a result, it was determined that political effect on SSCs prepared in different government periods and can be seen radical changes were made in terms of curriculum structure and content from 1998 to 2005 and that the SSC of 2018 is similar to that of 2005 in terms of structure.
\end{abstract}

Keywords: reconceptualization, political foundations, understanding curriculum as a political text, Turkish curricula, social studies curricula, citizenship education

\section{Introduction}

\subsection{Reconceptualization}

The movement of reconceptualization and curriculum understanding, investigating the political foundations and effects of curricula was started in the 1970s by William Pinar and Michael W. Apple. The advocates of this movement describe the traditional curriculum development approach (The curriculum and curriculum development approach led by Bobbit and shaped by Tyler) as monotonous and restricted by certain standards, causing inequality within and outside the school (Bümen \& Aktan, 2014; Ornstein \& Hunkins, 2014). This movement is also described as a movement based on the need to understand the curriculum in terms of racial, phenomenological, political, historical, and cultural aspects before starting the process of developing it (Pinar, Reynolds, Slattery, \& Taubman, 1995). Similarly, as described by Cornbleth (1988), understanding the curriculum is out of question unless the context (social, economic, and political) of the curriculum is seen (Pinar et al., 1995). In short, reconceptualization and the movement of understanding the curriculum is a movement that expresses the need to understand the curricula and opposes the traditional curriculum development approach. It is obvious that understanding the curriculum will significantly contribute to the development process of the curricula. According to the curriculum understanding movement it is deemed necessary to understand the curriculum as a political text that governments change through political foundations, in order to reveal these changes.

In the field of curriculum understanding as a political text, it is tried to reveal the political foundations and how the 
dominant power circles direct the curricula and the changes in the curriculum. Determining how and to what extent the states, governments, or hegemony, which is defined as the dominant power, affect the curriculum within the framework of political foundations is included in the study area of curriculum understanding as a political text. It is seen that the education definition of Sönmez (1996, p. 63) as "the process of transferring official ideologies to younger generations" emphasizes the political foundations of the curricula. Also, Apple's (1988, p. 201), one of the leaders of reconceptualization and curriculum understanding, statement of "Curricula... is a social product of competitive forces" emphasizes the hegemony of the government and ruling class in curricula (Pinar et al., 1995). In addition, it is stated that politicians make many changes in the context of the implicit curriculum by excluding educators, which indicated the degree of political influence on the curricula (Marsh, 2004). Althusser (1994), an important researcher on the oppression and ideological tools of states and ruling powers, notes that schools are covered with the ideologies of the sovereign power, that the state wants to impose its own political understanding on individuals, especially young people, and children and that it does so using curricula and schools. Also, is seen as normal for the state to make the necessary regulations for the knowledge and competencies of its citizens and especially for the new generation (Çetin, 2001). However, it is also stated that for the government to have a successful effect on education and curricula, it needs to consider some scientific data (Celkan, 2018; Sönmez, 1996). As can be seen, is can be said that the curricula are politically influenced by the official ideology of the state, together with the influence of the hegemonies who represent the dominant powers. In terms of citizenship education, we can say that the social studies curriculum (SSC) is the curriculum in which political influence can be seen more in terms of content.

\subsection{Social Studies}

Zarrillo (2016, p. 4) defined social studies as follows; "It is a study on the human being. Social studies should help children acquire knowledge, fully comprehend their learning processes, and become active citizens". It is seen that he emphasizes information and the process regarding active citizenship. In order to eliminate the differences of opinion on social studies and to reveal a common approach, the National Council for the Social Studies (NCSS) (1994) defines social studies as a field for developing social and humanity studies and citizenship competences in relation to many social sciences. The general goal of the social studies subject however is described as the development of knowledge, skills, and values for raising effective citizens (Doğanay, 2008; Öztürk \& Deveci, 2016; Sever, 2015). As can be seen, raising citizens as a content and target has an important place in social studies.

\subsection{Citizenship Education}

The understanding of raising citizens in education is also shaped within the framework of citizenship education. However, there is no common consensus on the content in citizenship education. Although it differs from state to state, it is defined as the process of preparing students as active citizens with the knowledge, skills and attitudes that will contribute to the development of the society in which they live in (European Commision, 2012, p. 8); as educating children as open-minded participatory citizens, participating in decisions about society (UNESCO, 2010 , p. 15) and as the process of preparing individuals and young people for citizenship with the awareness of their citizenship duties and responsibilities (Kerr, 1999). In addition, it is stated that citizenship education should also cover national identity and culture issues (Cogan \& Kubow, 1997; Kymlicka, 2001). Today, the approach accepted in citizenship education is; i) interdisciplinary curricula, ii) a separate subject, and iii) integrated with other subjects (European Commission, 2012; 2017). Goals in citizenship education are; “... enabling young people to become active citizens who contribute to the development of the society in which they live" (European Commission, 2012, p. 17) and "Recognizing management principles and institutions, learning to judge and criticize, and gaining a sense of individual and social responsibility" (UNESCO, 2010, p. 16). After talking about political foundations of the curriculum, the fact that political foundations coincide most with social studies in terms of content, how they direct citizenship education, reconceptualization, a movement examining political effects in curricula and understanding curricula as political text, there was a need to understand curricula as a political text within the framework of reconceptualization and curriculum understanding in order to see the kind of effects of political foundations on curricula. It is known that the content of political influence (citizenship, human rights, democracy, rights, and responsibilities, individual and society etc.) overlaps with the content of SSCs. Therefore, it is assumed that political influence can be seen most clearly in SSCs.

\subsection{Problem Situation}

Previous studies have been conducted in the fields of SSCs and citizenship education (Kara, Topkaya, \& Şimşek, 2012). However, no study regarding understand social studies curricula as a political text in the context of citizenship education has been found. Considering that the political effects of SSCs prepared in different government periods may reflect changes more clearly, understanding SSCs from 1998, 2005 and 2018 as a 
political text in the context of citizenship education within the framework of reconceptualization and curriculum understanding is seen as a problem situation in this study.

\subsection{Importance of the Study}

It is thought that this study will make important contributions to the literature in terms of i) curricula and teaching, ii) understanding curricula as a political text and impact on curricula as political foundations, iii) social studies and iv) citizenship education.

\subsection{Aim}

This study aims at understanding how politics affect curricula by examining social studies curricula as a political text in the context of citizenship education.

This study sought the answers to the following questions regarding the main questions: "In the context of citizenship education, what are the general views of academics and teachers about the political effects in the changes in SSCs of 1998, 2005 and 2018?":

1) How do academics and teachers define and explain political/non-political changes?

2) What are the criticisms of academics and teachers regarding the political/non-political changes in the curricula?

3) What are the views of academics and teachers about the reasons for the political/non-political changes in the curricula?

4) What are the recommendations of academics and teachers regarding political/non-political changes in the curricula?

\section{Method}

This study was produced from the thesis titled "Understanding Social Studies Curricula (SSCs) a Political Text in the Context of Citizenship Education" (Şiraz, 2020). The thesis consists of two stages. In the first stage the SSCs of 1998, 2005 and 2018 SSCs was examined in the context of citizenship education with review method. The second stage, based on the results of the first stage (examination of SSCs), covers the preparation of a semi-structured interview form to conduct semi-structured interviews with academics and social studies teachers. The basic assumption in the thesis was that political factors have a significant impact on SSCs.

\subsection{Model and Patterning}

This study was designed as a case study, a qualitative research method. Since qualitative research covers postmodern paradigm methods that serve to investigate perceptions and events in depth and in a holistic manner in the natural environment (Yıldırım \& Şimşek, 2013), it has been thought to be suitable for these research purposes (examining SSCs in depth and in a holistic manner). Operations and process of the study are shown in Table 1.

Table 1. Operations and process according to study stages

\begin{tabular}{|c|c|c|c|c|}
\hline \multicolumn{2}{|c|}{ Study questions according to stages } & \multirow[t]{2}{*}{ Data source } & \multirow[t]{2}{*}{ Data collection methods } & \multirow[t]{2}{*}{ Data analysis } \\
\hline 1) & $\begin{array}{l}\text { How do academics and teachers define and explain } \\
\text { political/non-political changes? }\end{array}$ & & & \\
\hline 2) & $\begin{array}{l}\text { What are the criticisms of academics and teachers } \\
\text { regarding the political/non-political changes in the } \\
\text { curricula? }\end{array}$ & \multirow{3}{*}{$\begin{array}{l}\text { Academics } \\
\text { Teachers }\end{array}$} & \multirow{3}{*}{$\begin{array}{l}\text { Semi-Structured } \\
\text { Interview }\end{array}$} & \multirow{3}{*}{$\begin{array}{l}\text { Descriptive } \\
\text { analysis }\end{array}$} \\
\hline 3) & $\begin{array}{l}\text { What are the views of academics and teachers about the } \\
\text { reasons for the political/non-political changes in the } \\
\text { curricula? }\end{array}$ & & & \\
\hline 4) & $\begin{array}{l}\text { What are the recommendations of academics and } \\
\text { teachers regarding political/non-political changes in the } \\
\text { curricula }\end{array}$ & & & \\
\hline
\end{tabular}

\subsection{Participants}

The participants in this study consisted of academics and social studies teachers. The participants declared that they participated voluntarily. The academics and teachers were determined by criteria sampling, a purposeful sampling method. The inclusion criteria for teachers were; i) being a social studies teacher and ii) having applied 
the 1998, 2005 and 2018 SSCs and inclusion criteria for academics were i) being an expert in social studies and ii) having done an academic study on citizenship education and/or SSCs. Statistical information on the academics and teachers are given in Table 2.

Table 2. Teacher and academics statistics

\begin{tabular}{|c|c|c|c|c|c|c|c|c|c|}
\hline & \multicolumn{2}{|c|}{ Gender } & \multicolumn{3}{|c|}{ Service time } & \multirow{2}{*}{\multicolumn{3}{|c|}{ Title }} & \multirow{2}{*}{ Total } \\
\hline & $\mathrm{F}$ & $\mathrm{M}$ & Min & Max & Mean & & & & \\
\hline Teachers & 2 & 5 & 16 & 28 & 22 & & $\begin{array}{c}\text { tial Studies Te } \\
7\end{array}$ & & 7 \\
\hline Academics & 1 & 7 & 6 & 28 & 17 & $\begin{array}{c}\text { Prof. Dr. } \\
3\end{array}$ & $\begin{array}{c}\text { Assoc Prof. } \\
\text { Dr. } \\
3\end{array}$ & $\begin{array}{c}\text { Dr. Faculty } \\
\text { Member } \\
2\end{array}$ & 8 \\
\hline
\end{tabular}

As seen in Table 2, the participating teachers were working in the city center Gaziantep and were working as social studies teachers. The participating academics were working at different state universities.

\subsection{Data Collection Tools}

Semi-structured interviews forms were used in this study as data collection tools (separately for academics and teachers).

\subsubsection{Semi-Structured Interview Form}

The semi-structured interview forms used in this study were prepared, based on the findings obtained from the document review of the 1998, 2005 and 2018 SSCs in the relevant thesis. The interview form consists of instructions and interview questions. A pilot application was carried out with a social studies teacher and it was determined that the semi-structured interview form was efficient.

\subsection{Data Collection Process}

In this study, interviews were conducted with teachers and academics about the political effects on the changes in SSCs. The face-to-face interviews with the teachers were carried out at their schools between April-May.2019 and the face-to-face interviews with the academics were carried out at their universities between May-September.2019. The interviews were recorded with a tape recorder, which were later transcribed to text and "participant confirmation" was received electronically and in writing. The interviews were realized in the work environment of the academics and teachers between 45-80 minutes.

\subsection{Data analysis}

The analysis of the interview data obtained in accordance with the purpose of curriculum understanding as a political text was done by content analysis method. The analysis of the interview data was made with the Maxqda2018.1 qualitative data analysis program. For the interview data in Maxqda2018.1 program the teachers were coded $(T 1, T 2, T 3, T 4, T 5, T 6, T 7)$ and the academics $(A 1, A 2, A 3, A 4, A 5, A 6, A 7, A 8)$. The data were primarily divided into political/non-political categories, in accordance with the study purpose and codes and sub-codes are determined under these two categories. In addition, in the political/non-political categories, the codes were themed as explanation and definition, reason, criticism and recommendation according to meaning relation. Political/non-political category and sample theme, category and coding are shown in Table 3. 
Table 3. Theme/category/coding process as an example of interview data

\begin{tabular}{|c|c|c|c|}
\hline Direct quote (teacher or academic code) & $\begin{array}{l}\text { Themes formed according } \\
\text { to meaning relationship }\end{array}$ & $\begin{array}{c}\text { Category } \\
\text { (Political/ } \\
\text { non-political) }\end{array}$ & Code/sub-code \\
\hline $\begin{array}{l}\text { While the curriculum is being prepared, the Ministry of } \\
\text { National Education calls and informs us that the } \\
\text { following subjects will be in the curriculum.(A1) }\end{array}$ & Reason & Political & $\begin{array}{l}\text { Education } \\
\text { Management/Turkish } \\
\text { Education } \\
\text { Board-Curriculum } \\
\text { development works }\end{array}$ \\
\hline $\begin{array}{l}\text { What kind of person do we want, reflection on general } \\
\text { purposes and how we will gain this, since there is no } \\
\text { holistic connection such as which gain, content, and } \\
\text { method, the focus lies on each learning area and each } \\
\text { learning area has a unit in a classroom.(A8) }\end{array}$ & Recommendation & Non-political & $\begin{array}{l}\text { Application-targeted } \\
\text { citizenship }\end{array}$ \\
\hline
\end{tabular}

As seen in Table 3, the codes generated with the interview data were categorized in political and non-political aspects. On the other hand, they were also themed in terms of meaning relations. Interview findings were presented under political and non-political categories under the themes of meaning relations (explanation and definition, criticism, reason, and recommendation) in accordance with the study purposes.

\subsection{Validity and Reliability}

Persuasiveness: Long-term interaction was provided in the analysis of the data and depth-focused data collection was performed.

Transferability: The process, method, reporting, and results were described in detail and the academics and teachers to be interviewed were determined with purposeful sample method.

Consistency: The data were collected in accordance with the study questions and the data analysis results were associated with the relevant study questions. During the preparation of the interview form, the expert opinion of Assoc. Prof. Dr., an expert of the fields of Social Studies and Turkish from Mersin University was obtained and necessary corrections were made in the form while constant contact was maintained with this field expert during the interviews. During the coding process of the interview data, constant contact was established between the authors of this study and the codes were arranged together to serve the study purpose. In order to reach the code similarity ratio, the interview data were coded by Faculty Member Dr. from the Educational Curricula and Teaching Department of Gaziantep University as second coder. This coder coded separately from the other coder (meaning relations for semi-structured interview data and political/non-political codes). It was seen that the code similarity between the coders was $90 \%$. Views were exchanged again for the $10 \%$ of codes, for which no consensus was reached, and these codes were combined with other codes.

Confirmation: Audio recordings of interviews, participant correspondence and interview confirmations, tables, documents, and coding are kept in a way that they can be examined by others when needed.

\section{Results}

In order to reveal the effects of political foundations on curricula, the interviews about 1998, 2005 and 2018 SSCs, which were applied during different government periods, were analyzed. The interviews were carried out regarding citizenship education about the 1998, 2005 and 2018 SSCs (general structure of SSCs, values, skills, attitudes, concept-name groups, citizenship approaches and political effects in SSCs etc.). Results are presented in the order of research questions. The process steps in the formation of the results are shown in Figure 1. 


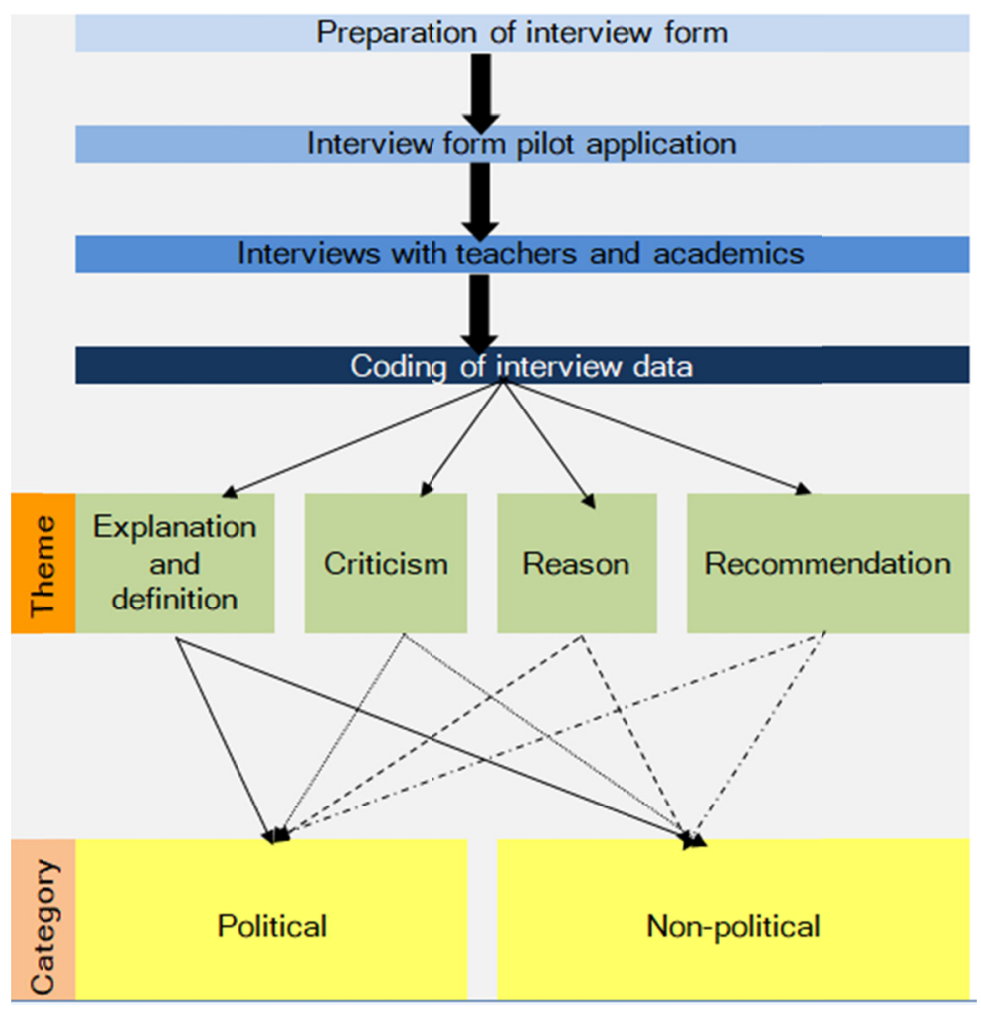

Figure 1. Study results steps

Structure of SSCs, values in SSCs, skills, attitudes, concept-name groups, citizenship approach, political effects and ideological curriculum approaches were tried to be examined and revealed with the interviews. Themes and categories obtained from the semi-structured interviews are shown in Figure 1. As seen in Figure 1, explanation and definition, criticism, reason, and recommendation themes were divided in themselves into political and non-political categories in the context of curriculum understanding as a political text. While thematization and categorization of the results were carried out, the focus was put on curriculum understanding as a political text and the context of "citizenship education".

The code numbers in the themes and categories created by the general results of the academic and teacher interviews about the SSCs in the context of citizenship education are shown in Table 4.

Table 4. Number of codes of the interview themes in the in political/non-political categories in the 1998, 2005 and 2018 SSCs

\begin{tabular}{lcccc}
\hline Themes & $\begin{array}{c}\text { 1998 SSC } \\
\text { (Pol./non-political) }\end{array}$ & $\begin{array}{c}2005 \mathrm{SSC} \\
\text { (Pol./non-political) }\end{array}$ & $\begin{array}{c}2018 \text { SSC } \\
\text { (Pol./non-political) }\end{array}$ & $\begin{array}{c}\text { Total } \\
\text { (Pol./non-political) }\end{array}$ \\
\hline Explanation and Definition (Political/non-political) & 113 & 152 & 151 & 456 \\
Criticism & $(38 / 75)$ & $(35 / 117)$ & $(39 / 152)$ & $(112 / 344)$ \\
(Political/non-political) & 120 & 198 & 363 & 681 \\
Reason & $(20 / 100)$ & $(31 / 167)$ & $(51 / 312)$ & $(102 / 579)$ \\
(Political/non-political) & 41 & 114 & 179 & 334 \\
TOTAL & $(24 / 17)$ & $(51 / 63)$ & $(85 / 94)$ & $(160 / 174)$ \\
(Political/non-political) & 275 & 464 & 733 & 1472 \\
Recommendation & $(82 / 193)$ & $(117 / 347)$ & $(175 / 558)$ & $(374 / 1098)$ \\
(Political/non-political) & & 410 & & 410 \\
TOTAL & & $(26 / 384)$ & & $(26 / 384)$ \\
\hline
\end{tabular}


As seen in Table 4, the code numbers of the 1998, 2005 and 2018 SSCs are seen according to themes and categories, and the suggestion theme includes all three SSCs. It was also determined that the political codes in all three SSCs were less than the non-political codes.

\subsection{Findings Related to the Study Questions}

The explanation and definition theme consists of two categories, political and non-political. The number of teacher/academic codes in the political category of the explanation and definition theme is shown in Table 5.

Table 5. Number of teacher/academic codes in the political category of the explanation and definition theme

\begin{tabular}{|c|c|c|c|}
\hline Codes & $\begin{array}{c}1998 \text { SSC } \\
\text { (Teacher/Acad.) }\end{array}$ & $\begin{array}{c}2006 \text { SSC } \\
\text { (Teacher/Acad.) }\end{array}$ & $\begin{array}{c}2018 \text { SSC } \\
\text { (Teacher/Acad.) }\end{array}$ \\
\hline There is a political influence & $2 / 10$ & $3 / 11$ & $5 / 12$ \\
\hline There is no political influence & $2 /-$ & $2 /-$ & $3 /-$ \\
\hline Curriculum ideology & $10 / 9$ & $6 / 9$ & $5 / 6$ \\
\hline Kemalism & $4 / 1$ & $1 /-$ & $1 /-$ \\
\hline Overseas influence & & $-/ 3$ & $-/ 1$ \\
\hline New Presidential government system & & & $2 /-$ \\
\hline July-15 & & & $1 / 3$ \\
\hline TOTAL & $18 / 20$ & $12 / 23$ & $17 / 22$ \\
\hline
\end{tabular}

As seen in Table 5, the frequency of the presence of political influence is higher in all three SSCs in comparison to no political influence. Of the academics A8 stated in regard to political influence: "Inevitably, what was valued in international relations during the curriculum preparation period at that time is reflected in the curriculum." and of the teachers T5 said the following in this regard: "Politicians and the dominant opinion definitely influence the existing, eliminated and newly added subjects and concepts in the curriculum." A5 of the academics said the following in regard to curriculum ideology: "We must say that one of the main ideologies and neo-liberalism in the world was seen in 2005 and 2018 SSCs." while T7 of the teachers said: "In 2005, within the framework of the European Union (EU) harmonization, a more global citizenship definition was made and I see that freedom and rights are more in the foreground." Of the academics A5 expressed the following regarding Kemalism "There was a little more political influence in the 1998 SSC." There was more pressure from the military and the subject of Kemalism was more prominent at that time." A5 while of the teachers T3 said the following "There was a more liberal approach to Kemalism in the 1998 SSC."

In terms of curriculum ideology, the 1998 SSC was described as having a Kemalist, nationalist and statist understanding. It was also stated that the $2005 \mathrm{SSC}$ was neo-liberalist, striving for EU harmonization and that the 2018 SSC had traces of globalization and neo-liberalist ideologies. The number of teacher/academic codes in the non-political category of the explanation and definition theme is shown in Table 6. 
Table 6. Number of teacher/academic codes in the non-political category of the explanation and definition theme

\begin{tabular}{|c|c|c|c|}
\hline $\begin{array}{l}\text { Codes } \\
\text { Sub-codes }\end{array}$ & $\begin{array}{c}1998 \text { SSC } \\
\text { (Teacher/Acad.) }\end{array}$ & $\begin{array}{c}2006 \text { SSC } \\
\text { (Teacher/Acad.) }\end{array}$ & $\begin{array}{c}2018 \text { SSC } \\
\text { (Teacher/Acad.) }\end{array}$ \\
\hline Curriculum development process & & $-/ 3$ & $-/ 2$ \\
\hline General Structure of SSC & $15 / 7$ & $27 / 37$ & $28 / 37$ \\
\hline Attitudes & & $-/ 5$ & $-/ 5$ \\
\hline Other course curricula & $6 /-$ & $6 /-$ & $5 /-$ \\
\hline Curriculum structure & $6 / 1$ & $7 / 15$ & $4 / 10$ \\
\hline Curriculum approach & $1 / 3$ & $6 / 5$ & $7 / 6$ \\
\hline Curriculum content & $2 / 1$ & $7 / 7$ & $6 / 5$ \\
\hline Curriculum skills & $-/ 1$ & $-/ 2$ & $1 / 6$ \\
\hline Curriculum values & $-/ 1$ & $-/ 2$ & $2 / 3$ \\
\hline General goal (GG)/Teacher Gains & & $1 / 1$ & $3 / 2$ \\
\hline Application & $4 / 1$ & $7 / 6$ & $10 / 6$ \\
\hline Application status & $4 / 1$ & $6 / 3$ & $8 / 4$ \\
\hline Teacher factor & & $1 /-$ & $2 / 2$ \\
\hline Measurement-evaluation & & $-/ 3$ & \\
\hline Content & $33 / 15$ & $23 / 14$ & $42 / 27$ \\
\hline Skills & & $2 / 2$ & $3 / 2$ \\
\hline Knowledge, science, and technology & & & $2 / 4$ \\
\hline Individual and society & $4 / 1$ & $3 / 1$ & $5 / 2$ \\
\hline Values & $9 / 3$ & $2 / 3$ & $5 / 4$ \\
\hline Democracy, groups, and governance & $1 /-$ & $2 /-$ & $7 /-$ \\
\hline People, places, and environments & $1 / 2$ & $2 / 3$ & $4 / 5$ \\
\hline Global connections & $2 / 1$ & $3 /-$ & $4 / 1$ \\
\hline National culture and identity & $2 /-$ & $2 / 2$ & $3 / 2$ \\
\hline SSC subjects & $5 /-$ & $1 /-$ & $2 /-$ \\
\hline Production, distribution, and consumption & & & $1 / 1$ \\
\hline Citizenship & $9 / 8$ & $6 / 3$ & $6 / 6$ \\
\hline TOTAL & $52 / 23$ & $57 / 60$ & $80 / 72$ \\
\hline
\end{tabular}

As the focus of this study lies on curriculum understanding as a political text, only a few important codes and participant views related to non-political results are given. As an example of the non-political category in the explanation and definition theme A2 of the academics sated regarding the curriculum development process the following "The 2005 SSC was created especially after $R$ and D studies and implementation in some regions." while no teacher made a statement in this regard. Within the sub-category of citizenship, the prominent citizen models according to SSCs were patriotic, socialist, good person, good citizen, responsible, ineffective, and active citizen in the 1998 SSC; free, competitive, capable of critical thinking and problem-solving citizen in 2005 and active, patriotic, and digital citizen in 2018.

\subsection{Findings Related to the Study Questions}

The theme of criticism is also systematically divided into two categories, political and non-political. In Table 7, the frequency of teachers/academics in the political category of the criticism theme is presented according to the three curricula. 
Table 7. Number of teacher/academic codes in the political category of the criticism theme

\begin{tabular}{lccc}
\hline $\begin{array}{l}\text { Codes } \\
\text { Sub-codes }\end{array}$ & $\begin{array}{c}\text { 1998 SSC } \\
\text { (Teacher/Acad.) }\end{array}$ & $\begin{array}{c}2006 \text { SSC } \\
\text { (Teacher/Acad.) }\end{array}$ & $\begin{array}{c}2018 \text { SSC } \\
\text { (Teacher/Acad.) }\end{array}$ \\
\hline Curriculum development process & & $-/ 1$ & $-/ 1$ \\
\hline General Structure of SSC & $7 / 11$ & $7 / 11$ & $17 / 21$ \\
Political/managerial issues & $5 / 7$ & $7 / 11$ & $17 / 21$ \\
GGs/ students outcomes (SO) & $-/ 1$ & & $1 /-$ \\
February 28 process & $1 / 2$ & & $1 /-$ \\
July 15 process & & & $2 /-$ \\
\hline Application & & $2 /-$ \\
Education tools/materials & $2 /-$ & $4 / 6$ \\
\hline Content & & $1 /-$ & $1 /-$ \\
Values & & & $-/ 1$ \\
Skills & $1 /-$ & & $1 /-$ \\
Targeted citizenship & & $3 /-$ & $1 /-$ \\
Kemalism & & $1 / 1$ & $1 / 5$ \\
People, places, and environments & $2 / 4$ & $23 / 28$ \\
National culture and identity & $1 /-$ & $14 / 17$ & \\
General content of SSC & $9 / 11$ & & \\
\hline TOTAL & & & \\
\hline
\end{tabular}

As seen in Table 7, of the academics A3 said regarding the curriculum development process: "I can say that the 2005 and 2018 SSCs are definitely a work of the government." while none of the teachers made a statement in this matter. A5 of the academics said regarding political/managerial issues: "The needs of time are reflected in the curriculum, and governments in countries like ours can influence curricula." and of the teachers T5 said: "Politicians and the dominant opinion definitely affect the existing, eliminated and newly added subjects and concepts in the curricula." Regarding GGs/SO A8 of the academics stated: "The government at that time (2005) gave much more priority to the EU. Such as EU-related legislation, which we see and feel in the curriculum." and of the teachers T1 said: "I think that there are gains in the curriculum that do not bring nationalism to the foreground." Table 8 shows the number of teacher/academic codes in the non-political category of the criticism theme.

Table 8 . Number of teacher/academic codes in the non-political category of the criticism theme

\begin{tabular}{lccc}
\hline $\begin{array}{l}\text { Codes } \\
\text { Sub-codes }\end{array}$ & $\begin{array}{c}1998 \text { SSC } \\
\text { (Teacher/Acad.) }\end{array}$ & $\begin{array}{c}2006 \text { SSC } \\
\text { (Teacher/Acad.) }\end{array}$ & $\begin{array}{c}2018 \text { SSC } \\
\text { (Teacher/Acad.) }\end{array}$ \\
\hline Curriculum development process & $-/ 9$ & $-/ 12$ & $-/ 18$ \\
\hline General Structure of SSC & $17 / 21$ & $8 / 23$ & $9 / 63$ \\
Others curricula & & & $1 /-$ \\
GGs/SO & $1 / 5$ & $1 /-$ & $2 / 7$ \\
Measurement-evaluation & $-/ 5$ & $1 / 6$ & $-1 / 9$ \\
Curriculum structure & $-/ 4$ & $1 / 3$ & $-/ 13$ \\
Skills in curriculum & & $-/ 1$ & $2 / 6$ \\
Values in curriculum & & $3 / 5$ & $-/ 13$ \\
Curriculum content & $2 /-$ & $2 / 5$ & \\
Curriculum compatibility & $-/ 2$ & & $-/ 3$ \\
Concepts & $2 / 3$ & & $3 / 3$ \\
Rote learning/authoritarian/knowledge transfer and & $12 / 2$ & $12 / 28$ \\
past emphasis & $11 / 17$ & $1 / 8$ \\
\hline Application & $4 / 3$ & $27 / 46$ & $19 / 21$ \\
Education environment & $6 / 4$ & $9 / 23$ & $56 / 71$ \\
Learning-teaching process & $-/ 3$ & $10 / 14$ & $15 / 35$ \\
Teacher factor & $1 / 7$ & & \\
Application status & $6 / 19$ & & \\
\hline Content & & & \\
\hline
\end{tabular}




\begin{tabular}{lccc}
\hline Kemalism & $1 /-$ & $2 / 3$ & $6 / 6$ \\
Skills & $-/ 2$ & & $-/ 19$ \\
Knowledge, science, and technology & & $7 / 15$ & $3 / 1$ \\
Individual and society & & $1 / 1$ & $6 / 5$ \\
Values & $1 / 6$ & $1 /-$ & $3 / 1$ \\
Democracy, groups, and governance & & $-/ 6$ & $-/ 6$ \\
People, places, and environments & $-/ 7$ & $-/ 4$ & $3 / 14$ \\
Targeted citizenship & $3 / 4$ & $1 / 1$ & $4 /-$ \\
Global connections & & $3 / 5$ & $12 / 5$ \\
National culture and identity & $1 /-$ & $50 / 117$ & $100 / 212$ \\
\hline TOTAL & $34 / 66$ & \\
\hline
\end{tabular}

As seen in Table 8 , the codes belonging to this category also apply to curriculum development process, general Structure of SSC, application, and content. As an example of criticism for the non-political category A3 of the academics said in regard to Kemalism as part of the content code: "In regard to general goals we see that the contents of Turkishness, Turkish History, Kemalism, Ataturk's Principles and Turkish revolution are reduced." and T1 of the teachers said: "Not much room is given to Ataturk in the 2918 SSC." In addition, in regard to targeted citizenship A8 of the academics said: "Unfortunately, the 2018 SSC mentions the subject of active citizenship, but we cannot see much of it within the gains." and T4 said in this matter: "Although most of the values are tried to be given in the current curriculum, it remains at the level of informed citizens."

\subsection{Findings Related to the Study Questions}

The reason theme consists of two categories, political and non-political. Table 9 shows the number of teacher/academic codes in the political category of the reason theme for the 1998, 2005 and 2018 SSCs.

Table 9. Number of teacher/academic codes in the political category of the reason theme

\begin{tabular}{|c|c|c|c|}
\hline $\begin{array}{l}\text { Codes } \\
\text { Sub-codes } \\
\end{array}$ & $\begin{array}{c}1998 \text { SSC } \\
\text { (Teacher/Acad.) }\end{array}$ & $\begin{array}{c}2006 \mathrm{SSC} \\
\text { (Teacher/Acad.) }\end{array}$ & $\begin{array}{c}2018 \text { SSC } \\
\text { (Teacher/Acad.) }\end{array}$ \\
\hline Ruing/dominant power & $5 / 6$ & $9 / 12$ & $20 / 15$ \\
\hline Curriculum development works & & $-/ 1$ & \\
\hline General structure of the curriculum & $2 / 6$ & $5 / 7$ & $9 / 4$ \\
\hline Content & $3 /-$ & $4 / 4$ & $11 / 11$ \\
\hline Education management/Turkish Education Board & $-/ 1$ & & $1 / 10$ \\
\hline Curriculum development works & & & $-/ 4$ \\
\hline General structure of the curriculum & $-/ 1$ & & $-/ 5$ \\
\hline Content & & & $1 / 1$ \\
\hline European Union & & $4 / 8$ & $1 / 2$ \\
\hline Curriculum development works & & $-/ 1$ & \\
\hline General structure of the curriculum & & $2 / 5$ & $-/ 1$ \\
\hline Content & & $2 / 2$ & $1 / 1$ \\
\hline Foreign countries & $1 /-$ & $5 / 13$ & $4 / 17$ \\
\hline Curriculum development works & & $-/ 1$ & \\
\hline General structure of the curriculum & $1 /-$ & $1 / 7$ & $-/ 6$ \\
\hline Content & & $4 / 5$ & $4 / 11$ \\
\hline July 15 process & & & $2 / 10$ \\
\hline Curriculum development works & & & $-/ 1$ \\
\hline General structure of the curriculum & & & $1 / 3$ \\
\hline Content & & & $1 / 6$ \\
\hline February 28 process & $4 / 7$ & & \\
\hline Social/economic cultural reasons & & & $-/ 3$ \\
\hline Content & & & $-/ 3$ \\
\hline TOTAL & $10 / 14$ & $18 / 33$ & $28 / 57$ \\
\hline
\end{tabular}

Table 9 shows the results regarding the reason theme in the political category. Regarding the theme general 
curriculum structure of the ruling/dominant power code A5 of the academics said: "Every state is founded on a certain ideology and wants to reflect this in the curriculum. It wants to see those characteristics in the citizen it wants to educate." and T7 stated: "Whatever the opinion of the party that came to power is reflected in the curriculum." In regard to the education management/Turkish Education Board within the theme general structure of the curriculum A5 said: "We were informed that these would not be included in the curriculum, and the works we prepared were removed from the program by the Turkish Education Board." and T7 stated "Whatever the opinion of the party that came to power is reflected in the curriculum." Table 10 shows the number of teacher/academic codes in the non-political category of the reason theme for the 1998, 2005 and 2018 SSCs.

Table 10. Number of teacher/academic codes in the non-political category of the reason theme

\begin{tabular}{|c|c|c|c|}
\hline $\begin{array}{l}\text { Codes } \\
\text { Sub-codes }\end{array}$ & $\begin{array}{c}1998 \text { SSC } \\
\text { (Teacher/Acad.) }\end{array}$ & $\begin{array}{c}2006 \mathrm{SSC} \\
\text { (Teacher/Acad.) }\end{array}$ & $\begin{array}{c}2018 \text { SSC } \\
\text { (Teacher/Acad.) }\end{array}$ \\
\hline Academic studies & $1 / 1$ & $2 / 3$ & $5 / 5$ \\
\hline Curriculum development works & & $-/ 3$ & $-/ 3$ \\
\hline General structure of the curriculum & & $1 /-$ & $2 / 1$ \\
\hline Content & $-/ 1$ & & $2 / 1$ \\
\hline Application & $1 /-$ & $1 /-$ & $1 /-$ \\
\hline Scientific/technological developments & & $8 / 2$ & $16 / 6$ \\
\hline General structure of the curriculum & & $4 /-$ & $4 /-$ \\
\hline Content & & $3 / 2$ & $10 / 6$ \\
\hline Application & & $1 /-$ & $2 /-$ \\
\hline Periodic needs & $2 / 2$ & $5 / 4$ & $11 / 5$ \\
\hline Curriculum development works & & $-/ 1$ & \\
\hline General structure of the curriculum & $-/ 2$ & $1 /-$ & $2 / 1$ \\
\hline Content & $2 /-$ & $4 / 3$ & $9 / 4$ \\
\hline Education environment & $2 / 9$ & $9 / 11$ & $6 / 5$ \\
\hline Curriculum development works & & $-/ 1$ & $-/ 1$ \\
\hline General structure of the curriculum & $1 / 2$ & $3 / 8$ & $4 / 3$ \\
\hline Content & $-/ 4$ & & $-/ 1$ \\
\hline Application & $1 / 3$ & $6 / 2$ & $2 /-$ \\
\hline Social/economic reasons & & $3 /-$ & $6 / 1$ \\
\hline Application & & & $2 / 1$ \\
\hline Content & & $3 /-$ & $4 /-$ \\
\hline Foreign countries & & $1 / 12$ & $2 / 15$ \\
\hline General structure of the curriculum & & $-/ 1$ & $-/ 2$ \\
\hline Content & & $1 / 11$ & $2 / 13$ \\
\hline Social view & & $3 /-$ & $11 /-$ \\
\hline General structure of the curriculum & & & $1 /-$ \\
\hline Content & & $2 /-$ & $6 /-$ \\
\hline Application & & $1 /-$ & $4 /-$ \\
\hline TOTAL & $5 / 12$ & $31 / 32$ & $57 / 37$ \\
\hline
\end{tabular}

As an example to the reason theme within the non-political category A2 of the academics said in regard to the scientific/technological developments code: "However, we see that factors such as the introduction of social media into our lives are reflected in the 2005 and 2018 SSCs." and T4 of the teachers stated: "Because of technological advances, smartphones, etc., the values we teach do not leave the room."

\subsection{Findings Related to the Study Questions}

The recommendation theme consists of two categories, political and non-political. Table 11 shows the number of teacher/academic codes in the political category of the recommendation theme for the 1998, 2005 and 2018 SSCs. 
Table 11. Number of teacher/academic codes in the political category of the recommendation theme

\begin{tabular}{lc}
\hline Codes & Teacher/Academic \\
\hline Kemalism & $1 / 2$ \\
Long-term policies in education & $2 / 1$ \\
Non-political education & $3 / 9$ \\
Regulation of the content of out-of-school factors in accordance with education & $1 / 4$ \\
Social/individual structure & $-/ 3$ \\
TOTAL & $7 / 19$ \\
\hline
\end{tabular}

The reason theme seen in Table 11 shows that the most frequent code in the political category is the non-political education code. A6 of the academics said regarding Kemalism "Kemalism is the cement of the Republic of Turkey. It should be included in the 1998, 2005, 2018 and 2023 curricula." and T3 of the teachers stated: "Subjects to Kemalism should be added." Regarding long-term policies in education A6 of the academics said: "Education should be self-contained and original and considered in the context of the past and the future." while T5 expressed: "I think that national education should not be planned with daily arrangements." Table 12 shows the number of teacher/academic codes in the non-political category of the recommendation theme for the 1998, 2005 and 2018 SSCs.

Table 12. Number of teacher/academic codes in the non-political category of the recommendation theme

\begin{tabular}{lc}
\hline Codes & Teacher/Academic \\
Sub-codes & $1 / 8$ \\
\hline Curriculum development process & $3 / 43$ \\
\hline General Structure of SSC & $1 /-$ \\
Increase and efficiency of academic studies & $1 / 6$ \\
Curriculum suitable for periodic needs & $-/ 3$ \\
Future oriented curriculum & $-/ 2$ \\
GGs/SO & $-/ 2$ \\
Measurement-evaluation system & $1 / 6$ \\
Curriculum skills & $-/ 22$ \\
Curriculum structure & $-/ 2$ \\
Curriculum evaluation & $105 / 157$ \\
\hline Content & $12 / 10$ \\
Skills & $5 / 1$ \\
Knowledge, science, and technology & $3 / 7$ \\
Being an individual and individualization & $27 / 25$ \\
Values & $2 /-$ \\
Democracy, groups, and governance & $13 / 13$ \\
Rights, responsibilities, and freedoms & $24 / 69$ \\
Targeted citizenship & $1 / 4$ \\
People, places, and environments & $3 / 9$ \\
Global connections & $11 / 18$ \\
National culture and identity & $4 / 1$ \\
Community life and us & $25 / 42$ \\
\hline Application & $2 / 1$ \\
Education environment & $9 / 12$ \\
Teacher factor & $11 / 20$ \\
Learning-teaching process & $3 / 9$ \\
Application status & $134 / 250$ \\
\hline TOTAL & \\
& \\
& \\
\hline
\end{tabular}

Regarding the topic of a suitable curriculum for periodic needs as an example for the theme of recommendation within the non-political category A6 of the academics said: "The curriculum must be future-oriented." and T1 of the teachers said: "The SSC needs to be updated as life changes." The sub-code frequency of teachers/academics in regard to the content related to targeted citizenship code were as follows: citizen loyal to Atatürk's principles and 
reforms (2/2), citizen who internalizes skills (-/1), conscious citizen (5/5), citizen who internalized values (3/1), digital citizen (-/2) active citizen (4/7) citizen looking into the future without losing the past (-/6), good human $(1 / 1)$, good citizen (-/2), global citizen (-/2), citizen committed to national/spiritual and cultural values (1/3), what kind of citizen (-/18), responsible citizen (3/1), citizenship transfer (-/3) and citizenship education (5/15).

\section{Discussion}

In this study, the views of academics and teachers regarding the 1998, 2005 and 2018 SSCs, which were prepared in different government periods, were obtained in order to analyze the political effects of the changes within these SSCs, in accordance with the reconceptualization and understanding the curriculum as a political text movement. The discussion was prepared in accordance with the study questions and the order of results findings in the political/non-political category, in order of the themes of explanation and definition, criticism, reason and recommendations.

It is explained that there generally is a political effect in the 1998, 2005 and 2018 SSCs and ideological dimensions in the curricula are defined. Prominent ideological elements in the 1998 SSC were more nationalist and statist, the theme striving for EU harmonization came forth in the 2015 SSC and globalization and neo-liberalist traces were found in the 2018 SSC. However, it is also seen that active citizenship practices are not sufficient in said SSCs. Similar to the results in the current study, it was previously determined that national consciousness, social harmony, and social identity in the 1998 SSC outweighed the other two curricula (Karasu Avc1, \& İbret, 2018) and that the subject of the Turkish World is missing in the 2005 and 2018 SSCs (Çoban \& Temir, 2017). Öntaş (2017) found, slightly different from the results of the current study, that the 2005 SSC had nationalist, democratic and liberal ideologies and republican and Kemalist elements at every class level. In the study it was found that the emphasis on Kemalism was more prominent in the 1998 SSC, while there was a more globalist approach due to the influence of the EU and abroad in the 2005 and 2018 SSCs. Similar to this result, Dinç and Doğan (2010) reported that there was a lack of Kemalism in the 2005 SSC and Aslan and Gökkaya (2004) found in their study the EU tends towards education and citizenship education rather than economy, and sets standards for the education systems of the member and candidate countries. In the current study it was observed that content code of the SSC was explained more than the general structure and application codes in the non-political category. Doğanay and Sar1 (2008) reported in their study that the implementation problems of the 2005 SSC were parents, society, equipment, physical conditions, and in-service training needs.

It was found that patriotism, socialism, and responsibility stood out as themes regarding targeted citizenship in the 1998 SSC, free, competitive citizens with certain skills in the 2005 SSC and again citizens with certain skillsets in the 2018 SSC. Similarly, Akpınar and Kaymakçı (2012) reported that there was an emphasis of citizenship within the GGs of the 1998 SSC but that there were new approaches in the 2005 SSC. It was also stated that there is no consensus on the definition of the citizen to be targeted (Çakmak \& Bulut, 2019) and there is also a study stating that the desired type of citizen is determined by the regime (Kara et al., 2012). Also, regarding citizenship education it was stated that although nine of the NCSS standards were included in the SSC, the fact that ideal citizenship and practices, which are the tenth standard, were not included, was inconsistent with the inclusion of the Effective Citizenship theme (Doğanay, 2008). It is understood that one of the most basic curricula, in which the targeted citizen criteria can be seen is the SSC.

It was observed that the code of the general curriculum structure in the political category was most criticized in the 1998, 2005 and 2018 SSC and that this criticism increased from the 1998 SSC up to the 2018 SSC. The most criticized sub-code regarding the criticisms about the general structure of the curriculum was that political/managerial elements influenced the curriculum. Ahmad (2004) found that Islamic elements are emphasized in social studies textbooks in Pakistan and that the dominant power opposes liberal curricula reforms during the curriculum development process. A study conducted for Bangladesh, Columbia, Mexico, and Canada showed that there is content determined by the government in social studies curricula (Bickmore, Kaderi, \& Guerra-Sua, 2017). There are also studies that indicate that globalization related to ideology in social studies should not be ignored in SSCs and that the negativities of globalization should be considered (Aslan, 2016; Gömleksiz \& Kılınç, 2012). It was found that in the non-political category the sub-codes of rote learning/authoritarian/knowledge transfer and past emphasis was criticized in the 1998 SSC, teaching-learning process in the 2005 SSC and teaching-learning process and application status in the 2018 SSC. Similarly, studies reported that a rote learning and teacher-centered approach was emphasized in the 1998 SSC and a constructivist approach in the 2005 SSC and that there are similarities between the 2005 - 2018 SSCs (Çoban \& Akşit, 2018; Sözen \& Ada, 2018). It can be said for all three SSCs that the applied curriculum differs from the official curriculum and that the problem of curriculum application negatively effects its efficiency. 
According to academics and teachers, the reasons for changes in the political category regarding citizenship education in the 1998, 2005 and 2018 SSCs were the February 28 process and ruling/dominant power in the 1998 SSC and ruling/dominant power in the 2005 and 2018 SSCs. Supporting the results of the current study, it was previously determined that political reasons for changes in the general structure of the SSC stemmed from the February 28 process in 1998 and the ruling/dominant power in the 2005 SSC (Akpınar \& Kaymakçı, 2012). While it was reported that EU norms impacted the $2005 \mathrm{SSC}$, development plans and government programs had an effect in 2018 (Çoban \& Akşit, 2018). Regarding the 2005 SSC it was also stated that education has been reconstructed due to the EU accession process, globalization, and integration with the world (Öntaş, 2017). It can be said that the political effect on the curriculum was caused not only by the government but also by the hegemony (dominant power) that existed at that time. Again, it was found that the most stated reasons for change in the non-political category were education-teaching environment in 1998 and 2005 and scientific/technological developments in 2018. Akpınar and Kaymakçı (2012) also emphasize the impact of scientific-technological developments from 1998 to 2018.

According to academics and teachers it was determined that the most stated recommendation in the political category regarding citizenship education was non-political education. Again, within the recommendation theme, the most stated recommendation in the non-political category was content. İmer and Kaya (2020) emphasize integrating digital citizenship into the programs in their study. In a study conducted in the USA on SSC recommendations, it was reported that social studies content and curriculum development should be more educational and aimed at instilling civic competence (Ollila \& Macy, 2019). It was recommended to be clear about the targeted citizenship and to benefit more from stakeholder opinions (Doğanay \& Sarı, 2008) and in addition, it was stated that the curriculum should be appropriate in accordance with the school characteristics, environmental conditions, expectations of administrators and teachers by adhering to the central standards of the curriculum (Bay, Vural, Kahramanoğlu, \& Aydın Aşk, 2016).

\section{Conclusion}

It is understood that there are political effects and some ideological factors in the 1998, 2005 and 2018 SSCs. The political effect focuses on the February 28 process in the 1998 SSC and on the ruling/dominant power in the 2005 and 2018 SSCs. It is seen that political influence guides both the general structure of the curriculum and the curriculum content. We can say that the dominant ideological concepts that exist in the SSCs also differ with political influence. In the 1998 SSC the content mostly focuses on Kemalism and nationalism while the 2005 and 2018 SSCs focus more on global content with overseas influence. It is understood that within the framework of political foundations, there may be a political impact on the curricula, but the scientific criteria that need to be taken into consideration regarding the political impact on the curricula must be meticulously followed. In addition, it was also determined that the targeted citizenship in the SSCs has also changed from 1998 to 2018 with political effects. However, it was concluded that there are problems in all three curricula (both in theory and in practice) regarding the targeted citizenship. And Apple's (1988, p. 201) statement of "Curricula ... is a social product of competitive forces" emphasizes is true. As a result, it was determined that political impact on SSCs prepared in different government periods can be clearly seen, that radical changes were made in terms of curriculum structure and content from 1998 to 2005 and that the SSC of 2018 is similar to that of 2005 in terms of structure.

\section{Recommendations}

According to the results of this study, in which the SSCs of 1998, 2005 and 2018 were tried to be understood as a political text in the context of citizenship education;

- We recommend to carry out discourse analysis within the framework of reconceptualization and curriculum understanding, studies to understand SSCs as a political text with government programs or election statements,

- To carry out studies with broad participation on citizenship education and targeted citizenship in SSCS and

- A curriculum compliance study to clearly reveal the problematic issues in SSCs.

\section{References}

Ahmad, I. (2004). Islam, democracy and citizenship education: An examination of the social studies curriculum in Pakistan. Current Issues in Comparative Education, 7(1), 39-49. Retrieved from https://files.eric.ed.gov/fulltext/EJ853848.pdf

Akpınar, M., \& Kaymakçı, S. (2012). A comparative view to Turkish social studies education's general goals. Kastamonu Education Journal, 20(2), 605-626. Retrieved from https://dergipark.org.tr/tr/download/article-file/806967 
Althusser, L. (1994). Ideology and ideological state apparatuses (4th ed.). (Y. Alp \& M. Özışık Trans.). İstanbul: İletişim.

Apple, M. W. (1988). Social crisis and curriculum accord. Educational Theory, 38(2), 201. https://doi.org/10.1111/j.1741-5446.1988.00191.x

Aslan, C. A., \& Gökkaya, A. K. (2004). Programme the politicis of the education system EC applies to the general aims of social science lesson. Gazi University Journal of Gazi Educational Faculty, 24(3), 227-244. Retrieved from http://www.gefad.gazi.edu.tr/tr/download/article-file/77302

Aslan, S. (2016). The effects of globalization on social sciences education. Harran Education Journal, 1(1), 11-23. https://doi.org/10.22596/2016.0101.1123

Bay, E., Vural, Ö. F., Kahramanoğlu, R., \& Aydın Aşk, Z. (2016). Teacher views on school-based curriculum development approach (an analysis of applicability in Turkey). Mustafa Kemal University Journal of Social Sciences Institute, 13(34), 180-201. Retrieved from https://dergipark.org.tr/tr/download/article-file/226448

Bickmore, K., Kaderi, A. S., \& Guerra-Sua, A. (2017). Creating capacities for peacebuilding citizenship: history and social studies curricula in Bangladesh, Canada, Colombia, and México. Journal of Peace Education, 14(3), 282-309. https://doi.org/10.1080/17400201.2017.1365698

Bümen, N. T., \& Aktan, S. (2014). A self-critical analysis upon Turkish curriculum and instruction field in consideration of reconceptualism. Kastamonu Educational Journal, 22(3), 1123-1144. Retrieved from https://kefdergi.kastamonu.edu.tr/index.php/Kefdergi/article/view/361/129

Çakmak, Z., \& Bulut, B. (2019). Global literacy skills from the social studies perspective. Mehmet Akif Ersoy University Journal of Education Faculty, 51, 160-180.

Celkan, H. Y. (2018). Educational sociology. Ankara: Asos.

Çetin, H. (2001). The state, ideology and education. Journal of Çukurova University Institute of Social Sciences, 25(2), 201-211.

Çoban, A., \& Temir, M. (2017). Academician's opinions on the subject of Turkish world and the effects of foreign policy in social studies curriculum. The Journal of Social Science, 4(18), 105-115. https://doi.org/10.16990/SOBIDER.3941

Çoban, O., \& Akşit, İ. (2018). Comparison of 2005 and 2017 social studies curriculum in terms of learning area, acquisition, concept, value and skill. Journal of History Culture and Art Research, 7(1), 479-505. https://doi.org/10.7596/taksad.v7i1.1395

Cornbleth, C. (1988). Curriculum in and out of context. Journal of Curriculum and Supervision, 3(2), 85-96.

Dinç, E., \& Doğan, Y. (2010). The views of teachers on the upper primary social studies curriculum and its practice. Journal of Social Studies Education Research, 1(1), 17-49. Retrieved from https://dergipark.org.tr/en/download/article-file/179012

Doğanay, A. (2008). Evaluation of the new social studies curriculum in the light of contemporary understanding. Journal of Çukurova University Institute of Social Sciences, 17(2), 77-96. Retrieved from https://dergipark.org.tr/en/download/article-file/50439

Doğanay, A., \& Sarı, M. (2008). The new social studies curriculum from the teachers' point of view: A study in the Adana province of turkey. Elementary Education Online, 7(2), 468-484. Retrieved from http://ilkogretim-online.org.tr/index.php/io/article/view/1827/1662

European Commission. (2012). Citizenship education in Europe (Report). Eurydice.

European Commission. (2017). Citizenship education at school in Europe (Report). Luxembourg: Publications Office of the Europe Union.

Gömleksiz, M., \& Kılınç, H. (2012). Views of academicians on the effect of globalization on curriculum: A qualitative study. Mustafa Kemal University Journal of Social Sciences Institute, 9(17), 397-413. Retrieved from https://dergipark.org.tr/tr/pub/ejer/issue/42446/511241

İmer, G., \& Kaya, M. (2020). Literature review on digital citizenship in Turkey. International Education Studies, 13(8), 6-15. https://doi.org/10.5539/ies.v13n8p6

Kara, C., Topkaya, Y., \& Şimşek, U. (2012). The place of active citizenship education in the social studies curriculum. Zeitschrift für die Welt der Türken Journal of World of Turks, 4(3), 147-159. Retrieved from https://www.acarindex.com/dosyalar/makale/acarindex-1423939304.pdf 
Karasu Avc1, E., \& İbret, B. Ü. (2018). An examination role of social studies course in the context of social identity formation: social studies curriculum. Adiyaman University Journal of Social Sciences, 29, 336-376. https://doi.org/10.14520/adyusbd.384963

Kerr, D. (1999). Citizenship education: An international comparison. London: Qualifications and Curriculum Authority. Retrieved from https://edudoc.educa.ch/static/xd/2003/59.pdf

Kubow, P., Grossman, D., \& Ninomiya, A. (1998). Multidimensional citizenship: education policy for the 21st century. In J. J. Cogan, \& R. Derricott (Eds.), Citizenship for the 21st Century: An international perspective on education (pp. 115-135). London: Kogan Page.

Kymlicka, W. (2001). Politics in the vernacular: Nationalism, multiculturalism, and citizenship. Oxford: Oxford University Press. https://doi.org/10.1093/0199240981.001.0001

Marsh, C. (2004). Key concepts for understanding curriculum (3rd ed.). New York, London: Taylor \& Francis e-Library. Retrieved from https://www.taylorfrancis.com/books/9780203870457?gclid=CjwKCAiA17P9BR B2EiwAMvwNyGwgkp3mipxxVVoaT1oSULeb4VF36qVzcbK20aOufeZUwJHrThOXVBoC7KkQAvD_B $\mathrm{wE}$

National Council for the Social Studies [NCSS]. (1994). Expectations of excellence: Curriculum standards for social studies. Washington.

Ollila, J., \& Macy, M. (2019). Social studies curriculum integration in elementary classrooms: A case study on a Pennsylvania rural school. The Journal of Social Studies Research, 3(1), 33-45. https://doi.org/10.1016/j.jssr.2018.02.001

Öntaş, T. (2017). Teaching social studies education in indoctrination and reproduction of ideology. Ahi Evran University Faculty of Education Journal, 18(1), 313-332. Retrieved from https://dergipark.org.tr/tr/pub/kefad/issue/59268/851438

Ornstein, A. C., \& Hunkins, F. P. (2014). Curriculum: Foundations, principles, and issues (A. Ar1, Trans.). Konya: Eğitim Kitapevi.

Öztürk, C., \& Deveci, H. (2016). Evaluation of social studies curricula of different countries. In C. Öztürk (Ed.), Social studies curricula of different countries (pp. 1-40). Ankara: Pegem Akademi.

Pinar, W. F., Reynolds, W. M., Slattery, P., \& Taubman, P. M. (1995). Understanding curriculum: An introduction to the study of historical and contemporary curriculum discourses. New York: Peter Lang Publishing.

Sever, R. (2015). Introduction to social studies teaching. In R. Sever (Ed.), Social studies teaching (pp. 1-24). Ankara: Nobel.

Şiraz, F. (2020). Understanding social studies curricula as a political text in the context of citizenship education (Unpublished doctoral dissertation). Gaziantep University, Gaziantep, Turkey.

Sönmez, V. (1996). Educational philosophy (4th ed.). Ankara: Pegem Yayıncıllk.

Sözen, E., \& Ada, S. (2018). Comparison of social sciences curriculum in the years of 2005 and 2018. Anatolian Journal of Educational Leadership and Instruction, 6(1), 53-71. Retrieved from https://dergipark.org.tr/en/download/article-file/498703

UNESCO. (2010). Citizenship education. UNESCO. Retrieved from http://www.unesco.org/education/tlsf/docs/module_7.doc

Yıldırım, A., \& Şimşek, H. (2013). Qualitative research methods in the social sciences (9th ed.). Ankara: Seçkin.

Zarrillo, J. J. (2016). Principles and practices of teaching social studies (4th ed., B. Tay \& B. Demir, Trans.) Ankara: Anı Yayıncılık.

\section{Notes}

Note 1 . This study has been derived his doctorate dissertation named "Understanding social studies curricula as a political text in the context of citizenship education" in Gaziantep University-Turkey, 2020.

Note 2. Limitations of the study: This study regarding curriculum understanding of the 1998, 2005 and 2018 SSCs as a political text is limited to the data obtained from the interviews with academics and teachers and does not include discourse analysis. 


\section{Copyrights}

Copyright for this article is retained by the author(s), with first publication rights granted to the journal.

This is an open-access article distributed under the terms and conditions of the Creative Commons Attribution license (http://creativecommons.org/licenses/by/4.0/). 